\title{
Disaster Education to Increase Family Resilience (Community Based Participatory Action Research on Post Flood Reconstruction Phase)
}

\author{
Ahyani Radhiani Fitri ${ }^{1}$, Desma Husni ${ }^{2}$ \\ \{ahyani.rf@uin-suska.ac.id ${ }^{1}$, desma.husni@uin-suska.ac.id $\left.{ }^{2}\right\}$ \\ ${ }^{1,2}$ State Islamic University of Sultan Syarif Kasim Riau, Indonesia
}

\begin{abstract}
Flood disasters experienced by many people in Riau require the role of Community Based Participatory Action Research (CBPAR). The research focuses on: potential challenges that will be defined in the community based on Participatory Action Research (PAR), process of developing and controlling collaboration, and challenges of subject collaboration in the research process. The purpose of this research is to increase family resilience in the post-flood reconstruction phase through CBPAR based on the concept of FEAR plan. Participatory action research is used as the research methodology. Research questions include: risk and protective factors related to disasters, family belief systems, family organizing patterns, and communication processes in families during the disaster reconstruction phase. The research subjects are 30 adults who experienced major flooding because the fifth door of the PLTA (Hydroelectric) Koto Panjang in Riau, which is closed for the last 30 years, is opened due to the overflow of several lakes in West Sumatra. Data of the research are collected using family resilience scale and questionnaire with open ended questions. The data are analyzed using qualitative methods by descriptive analysis. The results of this research show that there is an actively dynamic change of family resilience. The community is more aware of the importance of active participation activities to encounter problems related to flood disaster, such as disaster response plans, and complete preparation activities. Finally, they have practiced the implementation of disaster plan. In addition, the community has initiated meetings for youth and elderly focusing on the implementation of tiered activities so when the floods occur, the management of these activities can run independently supported by all of the community members. Community leaders have carried out double-level mentoring activities and have a good communication structure. Meanwhile, hey are still pioneering material through communication channels using the mosque.
\end{abstract}

Keywords: Disaster Education, Family Resilience, Reconstruction Phase,

Flood. 


\section{INTRODUCTION}

Geographically, Indonesia is one of country which is prone to natural disasters and humanmade disasters such as floods, landslides and drought. Flooding as a natural phenomenon associated with human activity occurs as a result of the accumulation of natural factors such as rainfall, river conditions, upstream conditions, and soil conditions (aqua culture areas and tides). The potential threat of this flood disaster can be caused by damaged river bodies, damaged water catchment areas, violations of spatial planning, high violations of law, less integrated development planning, and low community discipline [1]. Indonesia as "supermarket of disaster" with hundreds of tribes need to develop solutions coping with and/or adapting to hazards [2].

The adaptive disasters coping behaviors among Indonesian are needed since the lack of community knowledge and skills can be one of risk factor for disasters. Stern argues that the integration of one's own experience is a system that can be a burden in an under pressure condition especially disasters [3]. So, it will have a long term impact. According to Hamka in the interpretation of $\mathrm{Al} \mathrm{Mu'min}$ verse 29, the servants of God believes that the opportunities are given by God to maintain the earth well, fairly, and wisely. Allah explains the consequences if there is tyranny: "Then who will help us from disasters given by God if it comes upon us?" Then, God brings disaster and who seems to be able to fend off the disaster? It is because human and his energy are very limited [4].

Likewise, the flood disaster occurred in Riau hits the social system in twelve sub-districts in Kampar Regency. This is the worst flooding disaster during the last 40 years due to five water gates in the PLTA (Hydroelectric) Kota Panjang, West Sumatra, are opened simultaneously as the consequence thousands of residential settlements is flooded. This is because some people ignoring the notice through social media (Preliminary interview, 15 March 2016). Meanwhile, some of them didn't get written notification and short message so they did not have any preparation for flood disasters that may be occurred [5].

As a result of lack communication in the pre-flood phase, around 400 houses are flooded with water levels reaching 1.5 meters and the SAR team evacuates residents living in Graha Kualu Payung Sekaki, Kualu, Tambang, District of Kampar using many rescue cars and sea drivers [6]. As the consequent, residents unable to carry out their daily activities such as going to schools or workplaces [7].

Moreover, due to the geographical conditions, several families living in the banks of the Kampar River need to have recovery and prepare readiness to face flooding which can be occurs any time. This requires availability of supporting resources to shape family resilience within community members. Achievement of happiness and a better quality of life for family members can be done by forming a resilient personality. This can be done through analyze the causes of problems which refers to the individual's ability to accurately identify the causes of problems they faced [8].

The communities, especially families who became survivors, during the post-flood reconstruction phase requires further guidance so the survivors can be more resilient to regain their normal life as well as before the disaster occurred. Family members who become survivors experience different conditions of togetherness with their beloved so they need more functional adjustments to meet their daily needs and improve their happiness and quality of life [9].

Family resilience in the post-flood reconstruction phase requires psychological abilities, especially for flood victims who have suffered many losses and struggles due to flooding. Resilience in the community will grow and develop in every flood-affected community if they 
supported by resources that can be accessed easily and quickly. These supporting sources are availability of mosques as places for refuge that provide emotional, material, and existential support. Meanwhile, physical supports during critical phases is also needed in the form of food, shelter or temporary shelter, as well as spiritual aspect in terms of religious values, especially Islam. This is confirmed by the results of interview with administrators of the Sabaqol Mufarridun Mosque, in Tambang, Kampar, Riau. The data show that the mosque was also used as a place for evacuation of citizens who need facilities in a critical phase (Preliminary research interview, 27 January 2016).

Disasters not only cause panic but social disorganization. In addition, psychological problems which are consist of psychological distress (anxiety, depression, and grieving reactions), general distress (general stress levels), health-related problems (somatic complaints and sleep disorders), loss of social support and normal problem solving skills (reduced psychosocial resources), and problems related to adolescents and children are also experienced by communities that face the disasters. The participation of the community can increased family resilience in the form of support, protection, assistance or encouragement given from and for the family. This is carried out as a form of business appeal, and influences the family as a form of increasing family resilience. This is done by using the $4 \mathrm{R}$ model (Strengthening system with Risk Reduction, Readiness, Response, and Recovery) involving practitioners (disaster experts, psychologists), professional groups, government organizations, and nongovernmental groups as well as community groups and individuals who focus on risk factors, and protective [10]. Simon, Murphy, and Smith state about family resilience as family ability to respond positively to situations and conditions that damage family life. Therefore, rediscovering strong, resilient, and resistant feelings in which the family feels more empowered, and more confident than the previous situation [11]. Furthermore, education is one of the recommended way to promote family resilience skills.

Education might have specific impact on resolving disasters effects for a long term. This is because the higher education, the better skills they have to minimize spending levels after disasters. The educated people will have better psycho-social health than uneducated people. Education is associated with higher levels of resilience over the longer term that those with better education are more resilient, have a good psychosocial, and have more effective at taking on new challenges [12].

Increasing family resilience is needed for flood victims as a way to restore family functions after the flood. The role of education is needed by the family in order to survive and overcome problems in a positive way so they can rise from a stressful situation and not fall into a distress because they still have a long bright future. Families who have education to be able to rise up and fight the situation with full of various kinds of pressure are still able to survive in the future. The question of this research is: "What is the role of disaster education to increase family resilience in the post-flood reconstruction phase?"

\subsection{Research Method}

This research is conducted in a qualitative research using a descriptive analysis in community based participatory action research. Subjects in this research are citizens lived in Aur Sati, Tambang and Graha Kualu Payung Sekaki Housing, Kualu, Tambang, Kampar. The subjects are 77 adult who represent their family. Data of the research are collected using focus group discussion (FGD) method. The FGD are carried out in 3 times including FGD with community leaders, mothers, and youth. The research findings are organized and written descriptively based on the data found in FGD. In addition, researcher uses psychological scale 
where family resilience scale consists of 46 items and open-ended questions. Research analysis is done by open coding from the results of the Focus Group Discussion.

\subsection{Results and Discussion}

This research shows several essential finding as follows. The need for an increasing of family resilience is identified at the level of mothers and youths so they have to own an independent working mechanism and directly focus on solving problems, especially when floods occur. Meanwhile, as the strong force addressing problems related to post-flood reconstruction is fathers. The findings of this research assume that women and youths encourage to maintain positive situation in the future while they must solve the effects of blood disasters. According to Walsh, family resilience as a type of relational resilience to identify and foster key processes enable families to cope crises or persistent stresses caused within or outside the family more effectively [13]. In addition, the participants need regular simulations so not only women who understand how active community participate during floods and post-flood situation but the youth especially the member of mosque youth group take active behavior to increase their awareness. According to ESCAP, women and girls who often have limited access to information related to disasters reduce their resilience to disasters [14].

It is important to have disaster-responsive education to anticipate disaster negative impact at pre and post disaster phase. In fact, the subjects of the research have received a letter of appeal and messages on social media from the PLTA Service Unit of Koto Panjang to be careful and increase alertness due to the high rainfall which could impact on inflow so an overflow door might be opened and will cause flood. The family which have well preparation and planning to face the flood including pre (after getting information about the hydropower door opening), while, and post the flood disaster is still need to increase the awareness of how important of concrete activities in the form of post-flood simulations. The family gets sufficient social support (information, material, financial support) from BNPB (National Board for Disaster Management) and other voluntaries society. The finding of this research is the same as Huabio which is both individual and their families had no information, financial resources, emergency supplies, as well as social and networks support sufficiently during natural. The public health professionals should address to increase the awareness of a natural disasters through delivering continuous disasters education [15]. The interactive component of education are linked to this study as research findings, linking family learning and enthusiasm with the family resilience preparedness through community based participatory action research as the educational value among families and the partnerships (head of district and staff, BNPB, other volunteers from non-government organization and society).

Most of families participating in this research can promote adaptive resilience through focused group discussion with each other. However, men are still in charge of the communicating process and will play main role as the leader if a disaster is occurred. In this case, there is a significant lack of active participation among youths because they still need emotional support from adult (women and men) who will lead them to establish social religious program using facilities in the mosque. Furthermore, the head of district as one of the research subject expresses his thought fondly:

"Families anticipate flood disasters by doing preparatory activities to make sure that there will be no victims because the funds are often not given while the problem of flooding must be solved. The district serves social services which are negotiated with the National Board for Disaster Management, and 
the village officials always kept in charged. During the post disasters time, the families state there were advantages of flooding such as: clean yards, easier for fishing, natural fertilizer even though there were flood shortages such as submerged plants, child surveillance, and many infectious diseases. We have to do the cultural value to honor the nature and persuade each other to do positive activities together".

The received support typically shows increasing mobilization pattern in post-disasters and positively correlate to the level of exposure. Meanwhile, assuming the flood disaster preparedness in the future, most of family believes that they would solve the same problems by helping each other. They do the proverb "gotong royong" (cooperation) to make job easier after solving the life problems together, helping each other. Norris state that receiving support shows a mobilization pattern after disaster have positive correlation with the level of disaster exposure [16].

\section{CONCLUSION}

The results of this study found that several importance stage of resilience are overcoming problems by always thinking and acting positively, maintaining communication with families and formal sources from the government (information from the hydropower), BNPB (National Board for Disaster Management) and trying to manage financial aspect so they can survive when floods occur. Currently, the participants still need to have follow up activities to increase their readiness as problem solving preparation related to disasters. The suggestions of this research are the need for concrete training efforts for research subjects as initiation formation of a disaster alert team originating from, by, and for the community. This can be done through the cooperation of the government through the village government as well as support from BNPB Kampar. The procurement of water canals from the National Board of Housing, and relevant Non-Government Organizations as well as Corporate Social Responsibility from Private Parties who have provided financial assistance when the 2014 flood occurred.

\section{REFERENCES}

[1] Regulation of the Head of the National Board for Disaster Management of Republic Indonesia. 2008.

[2] L. Nuryanti, G. B. Sullivan, S. X. Wang, and P. Branney. Resilience as boundary object in disaster policy, research and interventions: border thinking from the Indonesian "Supermarket of disaster". 2017.

[3] J. Halpern, and M. Tramntin. Disaster Mental Health. Theory and Practice. 2007.

[4] Hamka. Tafsir Al Azhar. Juz VII dan Juz XXIV. Jakarta: PT. Pustaka Panjimas. 2003.

[5] Riau Television. http://www.youtube.com, accessed in March 13, 2016.

[6]. http://city.seruu.com/read/2016/01/21/270050/Perumahan-kuala-payung-sekakipekanbaru-terendam-banjir; accessed in March 13, 2016.

[7]. http://riausky.com/news/detail/5221/banjir-kampar-juga-genangi-perum-grahaumbrella-sekaki-warga-minta-dievakuasi; accessed March 14, 2016; Preliminary research interview in January 27, 2016.

[8]. K. Reivich, and A. Shatte. The Resilience Factor: 7 Essential Skills for Overcoming Life's Inevitable Obstacles. New York: Broadway Books. 2002. 
[9]. J. Halpern, and M. Tramontin. Disaster mental health: Theory and practice. Belmont, CA: Thomson Brooks/ Cole. 2007.

[10]. K. R. Ronan, and D. M. Johnston. Promoting Community Resilience In Disasters. The Role For School, Youth, and Families. New York: Springer. 2005.

[11]. E. Sunarti. Program Pemberdayaan dan Konseling Keluarga. Bogor: Fakultas Ekologi Manusia IPB. 2008.

[12]. E. B. Frankenberg, C. Sikoki, W. Sumantri, Suriastini, and D. Thomas. Education, vulnerability, and resilience after a natural disaster. Ecology and Society 18(2): 16. 2013.

[13] F. Walsh. The concept of family resilience: crisi and challenge. Fam Process, 35 (3): 261-81. 2013.

[14] ESCAP. Disaster Resilience for Sustainable Development. Asia-Pacific Disaster Report. 2017.

[15] X. Huaibo. Assessing Individual, Family, and Community Resilience to a Natural Disaster among Vietnamese Refugees in North Carolina: An Ethnographic Study. Dissertation. Greensboro: The University of North Carolina. 2011.

[16]. F. H. Norris, S. P. Stevens, B. Pfefferbaum, K. F. Wyche, and R. L. Pfefferbaum, Community Resilience as a Metaphor, Theoryu, Set of Capacities, and Strategy for Disaster Readiness. Am J Community Psychology. 41: 127-150. 2008. 